\title{
THE SOUTHEAST ASIAN CONTEXT
}

\section{Introduction}

Southeast Asia is, of course, much larger than Indochina as defined above and incorporates also the Philippines and all the islands in the East Indies archipelago, now known as Indonesia. New Guinea is on the border, notwithstanding the fact that half its territory is now Indonesia. This is not very relevant for our history of the opium problem. Many countries are located in this huge part of the globe (the East Indies archipelago is already as large as the United States).

In 1600 its population was estimated at just over 22 million. Vietnam, the largest country at the time, had nearly five million, Java four million, Burma three, etc. ${ }^{1}$ Two hundred years later the entire region had increased by about 50\%. Compared with most other large units (Europe, China, India, etc.) it had still a very low density of 5.5 persons per square kilometer (China had about 37). The endless wars and religious conflicts among the many kingdoms were the main reasons for this low population level.

The primary characteristic of Southeast Asia is the dominant islands populated with very different tribal people with many languages, and large stretches of sea separating them. Nearly all people, except a few on the large land masses, were more or less strongly oriented to the sea: ports, trade, pirates, merchants, foreigners, and many other mercantile features including shipbuilding, money-dealers, etc. belong to the standard "outfit" of Southeast Asia from its earliest history onwards.

The permanent labor shortages made "manpower" into a highly esteemed product and the target of the numerous pirate groups. They had the clear function of bringing people from areas with a "supply" to those with a "demand". Consequently, slavery had quite different characteristics under the indigenous peoples than under Western colonial masters. Apparently, warfare among the former had largely the function of "getting

\footnotetext{
1 C. Trocki (2006), p. 3 ff.
} 


\section{Total Consumption}

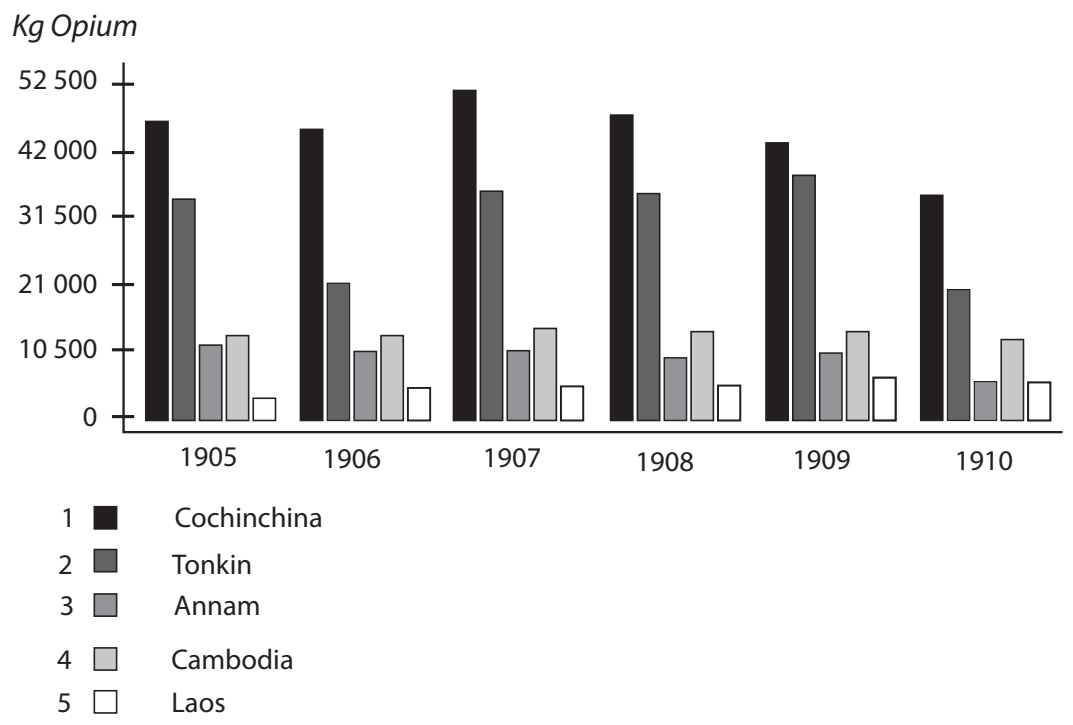

Consumption per Head per year, 1906-07

\section{Gram Opium}

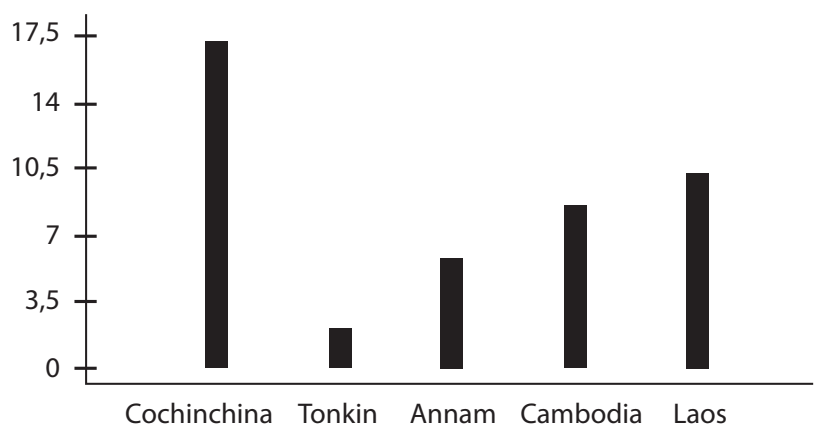

Figure 9. Total Opium Consumption in Indochina, 1905-1910 and the Consumption per Head, 1906-07

Source: C. Descours-Gatin, p. 211 according to Inspection Meray, rapportno.61; Memorandum Lauret, 1911. Also the Laos figures represent the results of the Opiumregie. It is too difficult to evaluate the results of the smuggling activities as well. For the consumption per user per year see table 29 .

people" more than killing, and never had the genocidal nature of the European assaults. Still, they were men-consuming ventures:

The larger states mobilized a substantial proportion of their male population into vast, ill-organized armies, without providing adequate supplies 
either for the soldiers or for their families left behind. Thousands of captives were marched back home by the victorious armies of Burma and Siam, or shipped home by Aceh and Makassar [pirates], with incalculable losses on the voyage. Perhaps an even more important factor demographically was the need to be constantly ready for flight in troubled times. This probably meant avoiding births at least until the older children were able to run by themselves. ${ }^{2}$

Colonization by Western powers was started first by the Spaniards in the Philippines; the Portuguese formed several settlements together into a rather busy trade network, but conquests of large tracks of land had no priority. The Dutch VOC conquered large parts of Java in order to consolidate its military and economic position, but the new Dutch regime in the East Indies in the 19th-century started with a rather systematic conquest of the whole archipelago.

At the same time the British and the French divided the heartland of Southeast Asia between themselves: the British conquered the Western, the French the Eastern part, and in between remained a large country, Siam, left colonized as a kind of buffer between the two foreign powers.

It cannot be a coincidence that the opium history was confronted here in the British and French colonies with most dramatic developments: the narco-military Western regimes changed into very powerful narco-military Southeast Asian regimes. The latter dominate today's opium and heroin production like the British did in the 19th-century.

The combination of the following table and figure 9 present the whole perspective for the next chapter.

Table 28. Southeast Asian Opium Cultivation and Heroin Production, 1992-1996 ${ }^{3}$

\begin{tabular}{lrrrrr}
\hline \multicolumn{1}{c}{1992} & 1993 & 1994 & 1995 & 1996 \\
\hline Net poppy cultivation in hectares & & & & \\
Myanmar (Burma) & 153700 & 165800 & 146600 & 154070 & 163100 \\
Laos & 25610 & 26040 & 18520 & 19650 & 25250 \\
Thailand & 2050 & 2880 & 2110 & 1750 & 2170 \\
Total & 181360 & 194720 & 167230 & 175470 & 190520 \\
Potential opium production in metric tons & & & & \\
Myanmar (Burma) & 2280 & 2575 & 2030 & 2340 & 2560 \\
Laos & 230 & 180 & 85 & 180 & 200 \\
Thailand & 24 & 42 & 17 & 25 & 30 \\
Total & 2534 & 2797 & 2132 & 2545 & 2790 \\
\hline
\end{tabular}

\footnotetext{
2 Quoted from Anthony Reid by C. Trocki, idem, p. 5, 6.

3 UNODC figures quoted from the Frontline website www.pbs.org.
} 
Table 28. Continued.

\begin{tabular}{lrrrrr}
\hline & 1992 & 1993 & 1994 & 1995 & 1996 \\
\hline Potential opium-heroin in metric tons & & & & \\
Myanmar (Burma) & 190 & 215 & 169 & 195 & 213 \\
Laos & 19 & 15 & 7 & 15 & 17 \\
Thailand & 2 & 4 & 1 & 2 & 2 \\
Total & 211 & 234 & 177 & 212 & 232 \\
\hline
\end{tabular}

The head of the United Nations Office on Drugs and Crime (UNODC) for East Asia, Gary Lewis, reported in December 2010 that the Burmese output had soared over the past four years to $95 \%$ of Southeast Asian production. ${ }^{4}$ Of this most is produced in Shan State, the large eastern part of Myanmar (Burma). In this "state" of military and criminals, there is a struggle for mastery over the opium-heroin-amphetamine, etc. resources. The last sentence of his article says:

'Most experts agree that as long as there is conflict in ethnic Burma, drugs production will follow as a means to fund it.' According to the UNODC Myanmar is pouring, probably the largest opium-heroin production over the Western world. And The Economist reports not only that the cultivation has increased by nearly $50 \%$ since 2006 , but also that now 'more than one million people in Myanmar are involved in producing opium, up $27 \%$ from the year before. 5

In this chapter we follow the history of this future until about 1950. We shall try to discover why this area became what it is now, described as 'Poisoned Hills' by the local, highly courageous Palaung Women's Organization in Burma. It recently accused the military and militias of many criminal deeds and atrocities against women, children and innocent people; in the end all opium-induced crimes.

\section{From "Golden Triangle" to "Bloody Quadrangle"6}

Even when describing the creation of the Golden Triangle, the ultimate opium logo of this part of Southeast Asia, historians cannot refrain from

4 Dan Withers on the website of Democratic Voice of Burma, 20 December 2010.

5 The Economist, 16th of March, 2010: 'Myanmar's opium crop. Steady hand on the till. But who is to blame for the spike in cultivation?'

6 Apart from the McCoy and Trocki studies, are used UN Special no. 626 (February 2004) written by Evelina Rioukhina (UNECE) on www.unspecial.org/UNS626/UNS_626_ To7.html and M. Jelsma, T. Kramer, D\&C, no. 16, August 2008. C. Lamour, M. Lamberti, part 2. 
pointing to 'ancient Greek fertility cults' as the 'first references to opium use' as if this should be relevant, although it is incorrect. ${ }^{7}$ B. Renard knows that the first references to opium use in Southeast Asia date back 'to 1366 (Thailand) and 1519 (Burma)'. The obvious conclusion is not drawn that Arab and Portuguese traders, respectively, must have brought some as a present to native rulers. Nowhere in those years did any form of largescale opium business in Asia exist, and there was no opium problem whatsoever.

Next, the information that in neighboring Yunnan (China) opium cultivation was introduced in the 18th-century 'from which it spread to northern Burma (Kachin State and Shan State) and Laos' is unreliable as well. In that century no opium was cultivated in China or Yunnan, and certainly there was no one who could expand into such a large area. More precisely:

In Southeast Asia the use of opium does not play an important role before the 19th-century. ... Generally it is true that opium consumption ... was initiated and stimulated by European merchants ... for profit. In Thailand, at that time still called Siam, the use of opium was introduced by the English, who discovered how they could smuggle opium under the British flag. ${ }^{8}$

The Yunnan invasion referred to above must be the one between 1870 and 1880: Hmong tribal people, who now knew how to grow poppies, were expelled by the Chinese military. They apparently taught other hill tribes how to grow this useful plant for their own consumption.

Early in the 19th-century indigenous rulers in Siam and Burma, like the Chinese emperors, strongly opposed the smuggling activities of the English and other Westerners (including Americans). Outside the tribal areas these rulers could prohibit the import and use of opium or tried to regulate them before they were overruled by the French or English.

In Siam there '... is a strong anti-opium movement ... resulting in the prohibition of selling and consuming opium of 1811 by King Rama II. Nearly ten years later, in 1829 , his son, Rama III, even ordered the death penalty for the opium trade ... Also in Burma, the kings prohibited the use of opium until 1852. When the English conquered parts of the south, the opium commerce started there. This happened in the form of a controlled monopoly by the occupying forces ... This expansion of the British continued, and in 1886 the Shan state of Burma was occupied as well. ... In Vietnam ... Cochinchina ... the government was also against opium use. Opium is prohibited

\footnotetext{
7 M. Jelsma, T. Kramer, D\&C, no. 16, p. 4.

8 D. Duco, p. 55 .
} 
by the court, while breakers of the rules were punished severely ... In the end opium use was accepted from 1857 onwards by the French colonists ... ${ }^{9}$

The opium is largely imported from Benares (India), and it is only in the period after 1880 that a change occurred from Benares import to Yunnan import, and the English started to complain about "Chinese competition". ${ }^{10}$

In short, the opium image still given in the usual touristic information: 'For centuries, these countries have produced the opium that has attracted traders from Europe and elsewhere'11 must be utter nonsense. It only fits the widespread "blaming the victims" stories (see ch. 29).

There is nothing romantic about this best-known Asian drug (opium, heroin, amphetamine) region. Its name is derived from the location where three countries, three nations and cultures come together: now the border zone of Thailand (Siam), Myanmar (Burma) and Laos with the river Salween in the middle. It forms a really symbolic triangle, each side belonging to another country. The triangle is a geographical mistake with several serious consequences. The fact is that it does not concern a borderland region of three countries, but of four.

Yunnan (China) is of strategic importance for the functioning of this "triangle" as opium center. Long after the British introduced opium as a mass product in China, that country developed the first counterattack through its own Chinese production (from around 1870 onwards). Yunnan became a center of Chinese opium cultivation (see ch. 31). We should therefore speak of the Golden Quadrangle. In reality, however, all the border regions together make up the center of the Burmese drugs business as quantified above and, therefore, one of the most criminal regions in the world.

Recently, The Economist published a news analysis about this same area, looking around in Meng'a, one of China's main points of entry into Myanmar. ${ }^{12}$ In quiet days Chinese from Yunnan arrive here on a day trip 'to escape their country's ban on gambling by visiting Bangkang's casino'. It is not quiet any more, however, because the usual mutual conflicts between the several militia - all very busy with the production and trade

Idem, p. 56, 57 .

10 C. Descours-Gatin, p. 209, 210.

11 E. Rioukhina, p. 3.

12 The Economist, 27th of November 2010, 'Myanmar's border with China. Good Fences.'. 
of opium, heroin or amphetamine-have started again, together with those against the junta in Rangoon. ${ }^{13}$

China faces a remarkable and complicated dilemma: it supports the junta because a new pipeline (gas and oil) from the Bay of Bengal had to cross Myanmar's territory. China also supported the militias because of their traditional ties with the Communist Party of Burma (CPB), from which some militias evolved many years ago. The junta also plays different games: it relishes China's backing in the UN, but it also courts China's rival, India. Last but not least, China is doing everything to fight drugs trafficking through its officials in Yunnan, and it has a keen interest in keeping the border areas calm because of its substantial investments in mining, rubber and other industries. If successful, the opium-stricken region would certainly be renamed a "Golden Quadrangle". But not yet: narcomilitarism can still be studied here first hand!

It must be clear now that neighboring China is historically and currently of the utmost importance for the fate of this whole Bloody Quadrangle.

Still, there are some grounds for optimism. In 1989 the US State Department, not the best source of information about drugs, told the world that the Golden Triangle 'produced a total of 3,050 metric tons of raw opium, equivalent to 73 percent of the world's total illicit supply ... America's leading single source of heroin'. ${ }^{14}$ This production has decreased as shown in table 28 , but it is practically impossible for it to increase again. However, McCoy points to the reality that 'the globe's great opium reserve in northern Burma had merged with the world's premier heroin market in the United States'. This foreshadows one of my main conclusions.

In his many famous studies, Alfred McCoy made crystal clear how

all Western attempts at interdiction ... have not only failed to eradicate this resilient global commodity, they have contributed, quite directly, to an expansion of both production and consumption. ... During the 40 years of the Cold War, moreover, government intelligence services, particularly

13 The ethnic militias in the border areas between Myanmar and China are: in the northern so-called Kachin State operates now the Kachin Independence Army (KIA); more to the south in the Kokang region and the "Special Region no. 2" (with cities like Meng'a and Bangkang) the largest army of the United Wa State Army (UWSA) with 20,000 wellarmed soldiers; along the border of China, Laos and Myanmar the National Democratic Alliance Army (NDAAD) is active. In addition, in the so-called Shan State, a large potential of junta enemies are concentrated with a highly militant tradition.

14 A. McCoy in A. McCoy, A. Block (ed.), p. 237. 
the ... CIA ... served as protectors of Southeast Asia's key opium traffickers ... contributing to an initial expansion of production and the failure of later interdiction efforts. ${ }^{15}$

Therefore, what is it about this area? This question should be answered from the perspective of the French colonization and not so much from its "use" after $195^{\circ}$ by the CIA or any other power. McCoy has great merits in uncovering the Cold War's strategic use of opium; its pre-history is highlighted below in which none of the opium parties in Southeast Asia even dreamed of the production figures and position in the world's drug scene today.

\section{The Tribal Scene}

Traditionally, opium has been used in the many tribal regions of Southeast Asia for a variety of purposes. We still do not know whether it originated as a custom brought centuries ago by Arab, Portuguese or Dutch merchants or colonizers. Anyway, for the 18th, 19th and a large part of the 2oth centuries, tribal people in Southeast Asia (not the urban population) must have perceived opium use as a genuine indigenous custom.

It is used medicinally to cure diarrhea, to lessen the effects of malaria, to reduce heart palpitations and as a painkiller and tranquilizer. It was also employed in veterinary medicine. A village custom in parts of Southeast Asia used it to cure animal diseases, but most importantly it could be applied to tame and train elephants for all forms of heavy work and transport. Furthermore, poppy seeds (graine de pavot) were used to give flavor to bread or other culinary products and to made oil (l'huile d'oeillette). Last but not least, there was a specific recreational use of opium smoked mixed with tobacco or drunk in tea.

This means that the poppy plant was a rather elementary part of the daily life of indigenous people in the villages. A substantial part or all of this consumption could be grown locally. It was perfectly relevant, effective, good, legitimate and so on and was derived (sometimes still is) from old tribal wisdom and knowledge.

A comparison with the European situation from before 1800 is quite revealing. ${ }^{16}$ The main difference is that the Southeast Asian tribes could grow poppies for themselves and, therefore, could discover many more

15 Idem, p. 238.

16 See ch. 8 for England, ch. 10 for Portugal, ch. 13 for the Netherlands and ch. 22 for France. 
applications than just medicinal ones over the course of time. In both cases the use of opium was for a long time an intimate part of their daily life, without all kinds of legal or criminal obstructions. And in both cases this situation came to an end and was transformed into an external matter of fear and repression.

In the European case a combination of external factors (state repression, differentiation of class interests, religious-moral repression, Enlightenment, development of specific modern health infrastructure) also put an end to the home-oriented use of opium embedded within a mixture of social and cultural customs and related knowledge. Here in Southeast Asia the foreign colonial regime and its rigorous settler's activities insisted on destroying the indigenous belief systems and customs. Also here, the relationship between Enlightenment and modernized imperialism is important to consider (see ch. 28 the Philippines case). What may be left of it today should be good for tourism only.

All this is symbolized in the orders of the French and English colonial states: indigenous opium is forbidden, and only the French and British opium regimes are allowed. This is accompanied by the French and English definition of power for their religious representatives: opium is a social evil that needs to be banned. Modern, imported knowledge (medical, pharmaceutical, chemical and the like) of an "isolated" kind must replace the comprehensive and socially embedded knowledge of the tribal people.

In the meantime there was a traditional need for opium which could only be satisfied by external economic interests: locally grown poppies were forbidden in favor of European-owned or -guided interests based on strong state support. The criminalized villagers suddenly became dependent on external powers (state bureaucrats, military, missionaries) and their criminal supporters (tax farmers, for instance): the only thing which was left for them was to revolt or resign, to defend their traditions or remain isolated in a new urban society with a foreign character.

Long after this, the drama enrolled as reported:

Those that relapsed became seen as failures holding the village back from the fruits of modernization that development agencies and government officials are promising to the "model" villages that are relatively successful in removing opium addiction ... This adds to the sense of shame and hopelessness that many opium smokers feel and only increases their dependence on opium ... Regardless of the fact that the pervasive presence of opium and its practical and symbolic value in specific medical or social contexts makes abstinence a difficult and at times impossible task, addicts are increasingly 
marginalized because of their imputed personal responsibility for their addiction and its implications for the village's material development. This kind of punitive atmosphere began creating a sub-population of "degenerate addicts". ${ }^{17}$

This statement concerns village life in Laos. After many interventions by the state, military or "modernizing" expatriate developers, the old bonds were fully destroyed. Too many people became defenseless individuals. After the colonial wars were over and a new power vacuum was filled, opium consumption rates in the rural areas soared to the highest in the region. Many people were unable to stand the alienation and to fulfill the expectations of a strange, modern, urban world; they fell victim to the urban opium criminals. This pushed them into a fully hopeless situation of dependence on heroin. Opium use was decreasing, but opiate dependence increased.

That was the situation in village life in this part of Asia from around 1980 onwards. But let's return to the 1940 s and 1950s, and provide more details about this tribal scene in Southeast Asia, because there are many misunderstandings circulating about it.

The third Western colonial government involved in large-scale opium production and trade, the French, had a monopoly for its own Southeast Asian colonies. Not only did its colonial activities have widespread effects in the whole of Southeast Asia, but the same effect was gained as in the British-Chinese relation (see part two and ch. 30): in the propaganda, the victims were transformed into the perpetrators as a whitewashing campaign of the white colonizers. By the end of this "game", some victims indeed acted as perpetrators and acknowledged the prejudice. In Southeast Asia some tribes underwent this fate.

The peculiar characteristic of Southeast Asia is that without a substantial and, in fact, powerful tribal scene, opium production or distribution or trade was very difficult. This is true not only for the period after the end of the long 19th-century. Tribes have been settled in the hills of the Chiang Rai area for centuries (the Akha, Lahu, Lisu, Mien, Hmong, Shan or Thaiyai, Mon and Karen). A certain symbiosis between these areas with their wild nature, colorful tribes, rather militant tribal life and opium production and trade easily leads to exaggeration. One always hears, "Opium has been here already for centuries" which is a quasi-truth never properly substantiated.

17 Quoted by M. Jelsma, T. Kramer, D\&C, no. 16, p. 22. 
The Akha are very tradition-bound and well-known for their attractive dresses, wearing skilfully embroidered silken jackets in their everyday life. The small group of the Lahu live in villages located above 1,00o meters. They farm poppies, dry rice and corn as cash crops. Many of them have been converted to Christianity. The Lisu form the smallest tribal group in Thailand. They arrived from Burma in 1920, live at a very high altitude, and are well-known for their hard work and competitiveness. They are considered the most successful of all Thailand's tribal people. The small tribe of the Mien are in all respects the most Chinese oriented. They practice rotational agriculture, depending more on rice and corn rather than poppies.

More to the east, in Vietnam the ethnic situation is possibly even more complicated, although most people are not aware of it. They think of Vietnam only in terms of its lowlands and the Kinh (ethnic Vietnamese), which is understandable because the Kinh (literally: 'people of the capital') form the majority (85\%). However, Vietnam is three-quarters mountainous and hilly, in which about $20 \%$ or 14 million of the inhabitants live. ${ }^{18}$ There are seventeen ethnic groups. In Vietnam at the moment, opium does not play a significant role among these ethnic groups. We have to turn, therefore, to the three most important tribes in the Southeast Asian opium story: the Shan, Hmong and Karen (or Red Karena).

They are border tribes connecting Burma, Thailand, Laos and China, countries which share over 1,00o miles of border. Historically, they suffer and benefit from their buffer position between often warring countries. The border tribes constantly have to choose, switch and deal in order to survive. After about 1960 the direction of their choice was clear: most tribes were against the Burmese military regime and pro-Thai. A few remarks about the Shan and Hmong can clarify the previous picture.

\section{The Shan State}

For the Shan there are specific reasons for maintaining a peaceful relationship with Thailand and hostility against Burma. The former serves as the transit and refining area for the annual 400-70o tons (1980) of opium from the Shan, while Thailand's main cities (Bangkok, Pang, Mae Hongson, etc.) are centers from which heroin trafficking is financed and controlled. The Burmese military regime, however, is very eager to control the Shan

18 For the following see the article of A.T. Rambo and N. Jamieson, in: H.V. Luong (ed.), p. 139-171. 
State itself so that the opium, heroin or morphine revenues can support its despotic regime.

In 1956 the CIA concluded that 'the majority of opium exported from Burma originates in the Shan State' and 'that the annual production of opium in Burma is at least 150 tons' ${ }^{19}$ This is an estimate for the whole of Burma and still very far from the 400-700 tons estimated 30 years later just for the Shan State. Estimates in these cases, however, remain guesses, too often "political guesses".

So, first, who are these Shan? A short "opium answer" must suffice here. Immediately after the end of World War II, Burma became independent of the British colonizers. The British Empire withdrew in disgrace, leaving a social, cultural and economic mess behind, as it did in Palestine, India, and so on. We may consider what was "better" measured by the quantities of blood shed: a direct liberation war against the British or the prolonged massacres which still continue today in Palestine, Kashmir and Burma. As usual, the British took the cheapest option, although they must have known what would happen later.

In Burma, for instance, representatives of the Shan together with the Kachin and Chin tribes (the United Hills Peoples, SCOUHP) met in February 1947 in Panglong to conclude agreements with representatives of the Executive Council of the Governor of Burma. A few days earlier the SCOUHP had already concluded a mutual agreement supporting each other's right to form an independent state and 'to secede after attainment of freedom from Confederation with Burma if and when we choose'. ${ }^{20}$

The representative of "Rangoon", Aung San, accepted an agreement in which, for instance, 'a separate Kachin State' was envisaged, the citizens of the 'Frontier Areas shall enjoy [democratic] rights and privileges' or that they were 'entitled to receive from the revenues of Burma ... similar to those between Burma and the Federated Shan States'. Aung San, however, was killed soon afterwards in a military coup.

The Shan exile, Chao Tzang Yawnghwe (alias Eugene Thaike), is an eloquent supporter of the Shan case. He was chief-of-staff in the Shan State Army (SSA) until 1976 and one of the very few people who can explain the local opium situation well. He is very critical of the frenzied efforts by governments and international agencies to eradicate opium in Burma

19 Central Intelligence Agency, p. 8.

20 In the appendices of C. Yawnghwe, p. $253 \mathrm{ff}$. the relevant documents are given. "Rangoon" was also defined as 'Interim Burmese Government'. 


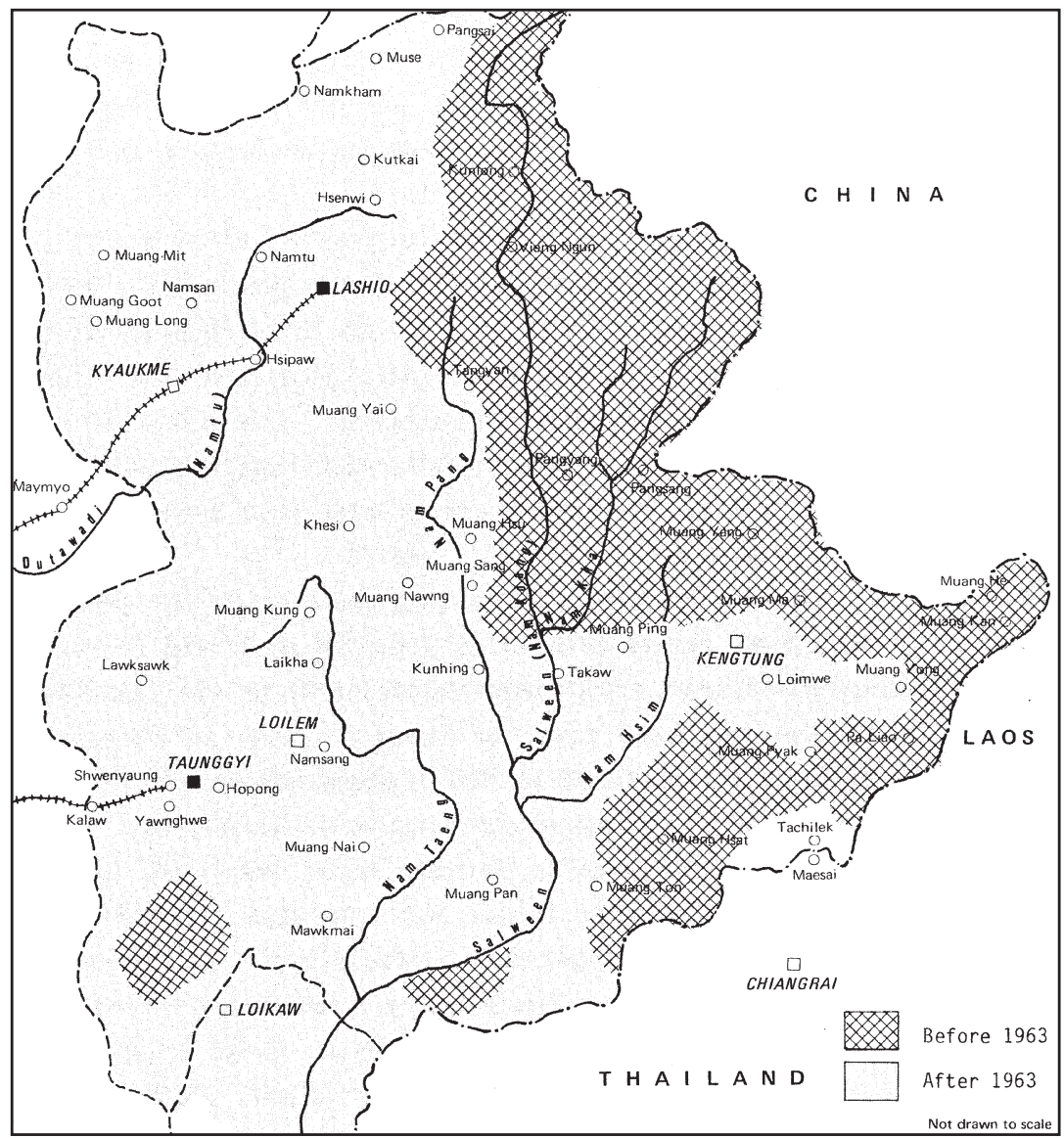

Map 13. Opium Cultivation in Shan State before and after 1963

Source: C. T. Yawnghwe, p. 56. Compiled from "Situation Reports and Intelligence Data', Shan State Army GHQ Office, 1963.

through Thailand, 'which is like trying to pull out a tooth in order to cure a stomach-ache'. ${ }^{21}$

What is the independent opium view of this Shan nationalist, who seems to be a monarchist as well? Yawnghwe:

Why is opium extensively cultivated in Shan State? Is it, as alleged by Rangoon, because the Shan and tribal peasants are forced by Shan rebels and the CPB [Communist Party of Birma] to do so? It is not easy to force peasants to grow anything since there are many ways to get around such com-

21 Idem, p. 268. 
pulsion. For forced cultivation of opium to succeed, it must be run plantation-style with peasants forced into barracks under guard, among other things, which implies that rebel armies must hold secure areas, and this has never been the case. ${ }^{22}$

The next question he tries to answer is whether the peasants grow opium for profit. The obvious affirmative answer is not given; Yawnghwe first points to many other things. A peasant rarely makes substantial profit from what he grows. In addition, he states that a peasant family growing opium under the best weather, soil and social conditions 'will produce at most about $12 \mathrm{~kg}$ a year'. He continues with a realistic economic analysis:

The field price of one kg of opium is as follows: 300 kyat in the mid-196os; 600 kyat in the early 1970 and 1000 kyat in the early 1980 (kyat and baht are about equal, unofficially). It is indeed rare for a family to be able to produce the maximum amount. However, let us say that a certain peasant family did produce $12 \mathrm{~kg}$ of opium in 1980. Its annual income would be 12,000 kyat or baht ... In terms of purchasing power, the family's maximum income would ... be only 4,0oo baht (less than $\$ 250$ ) a year. The vast majority earned far less. ... Most opium cultivators, moreover, like most peasants of Southeast Asia, are indebted to buying agents or local moneylenders before planting and have to hock the yield, or borrow usually at 30 to $5^{\circ}$ per cent interest per season. It is thus amply clear that Shan and other tribal peasants are not growing opium for profit. $^{23}$

Yawnghwe agrees with comments that opium cultivation is widespread in the Shan state, but this would have amounted at most to 6o-8o tons in 1958. The government in Rangoon made of this 400-6oo tons in 1970; Washington and the United Nations repeated this without any form of investigation. This is unbelievable, 'a revolutionary leap never seen before in agricultural history ...' Rangoon made a mess of its statistics, while it 'does not control the rural areas'.

The true cause of the Shan opium and heroin trafficking is 'a deep economic, social, and political malaise arising from Rangoon's harsh rule, economic foolhardiness, and arrogant defiance of socio-economic and political realities'. ${ }^{24}$ In addition, in all their proposals to end the opium problem, the Shan always welcomed foreign observers. Rangoon, however, always told the international community that the opium and heroin problem was 'our internal affair and concerns no one'.

\footnotetext{
22 Idem, p. 55.

23 Idem, p. 57.

24 Idem, p. $5^{8 .}$
} 
Rangoon's solution to the Opium Problem is: "Eliminate Shan rebels!" It immediately received international military aid. This is comparable to the century-old creed in the "Dutch" East Indies or in "British" India when the British stopped their own activities: "The Smuggling" prevents us from eradicating the Opium Problem consistently and gradually. The true reason for this was that the "government" wanted to have the monopoly without any form of opposition or 'free trade' (see Opiumregie policy).

In addition, the international military and/or economic aid was given wholeheartedly in the framework of some "domino theory" to encircle Chinese Communism. But Rangoon's problem lies elsewhere: its nationalism is an ethnic nationalism

trying to impose its concept of nationhood on the other by force ... to subjugate them or destroy their ethnic identity. Rangoon's attempts to gain control over the various homelands is, therefore, linked to the problem of narcotics only because of negative and short-sighted policies. A solution lies ... in ... what is known as "good government", a relevant and rational point which international policy-makers, bureaucrats, and scholars gloss over when discussing the problem of drug trafficking in Burma. ${ }^{25}$

Yawnghwe adds to this argument a clear threat: in 1961 the Shan rebels totaled not more than 1,500 men, but twenty years later they are a wellarmed army of 7,000 to 9,00o men, which is fighting in its own familiar territory. He suggests that even with Western military assistance, there is no chance of an easy victory, while in the end only the CPB will come out as the winner, 'through its ability to provide arms, be able to take over the various nationalist movements and armies'. ${ }^{26}$

Nationalists fighting nationalists while both have "foreigners" as enemies, the Communists, and both have an ambiguous relationship with Westerners.

\section{The Hmong tribe}

The Hmong or Meo became notorious by collaborating with the USA during the Vietnam War. Earlier they also had a remarkable history:

Between 1898 and 1922 Hmong rebelled against colonial rule; however, relations improved in the 1940 s once the French used Hmong opium to supply state-run opium dens throughout Indochina and later, employed

\footnotetext{
25 Idem, p. 60.

26 Idem, p. 59.
} 
Hmong guerillas to resist Viet Minh (Vietnamese communist) efforts to establish a bridgehead in northern Laos. ${ }^{27}$

Thanks to their assistance given to the American forces, many Hmong were allowed to come to the USA. ${ }^{28}$

The Hmong number about 65,000 in Thailand (in 2000). Paul Hillmer, their most recent historian, perfectly demonstrated the ambiguous effects of prejudice. To undermine them, he states that among the Hmong, opium has only a limited use as a folk remedy, stimulant, and pain reliever... while opium addiction exists, it was rare and socially stigmatizing ...29 However, only a few lines further on, we can read that opium is primarily used

as a cash crop-both to pay taxes, a practice encouraged by the Lao government and the French colonizers, and to trade in exchange for other necessities. Opium netted a family more wealth per acre than the other crops they grew.

Here the mechanism is indicated thorugh which regular opium production as a cash crop is provoked. In the meantime the Hmong sometimes played an important role in the whole "triangle-quadrangle game" in Southeast Asia, in war and peace. In the highly complex situation of Southeast Asia it is often difficult to discover who was first and who has to follow along as a mere act of survival or out of existential fear for repercussions. Whoever is prepared to take a more independent stand will certainly point to the devastating role of the former colonizers the Meo were familiar with, notwithstanding their bad press as collaborators of the French and Americans.

During World War II the French officials exploited the tribal opium sources in "good collaboration" with the Japanese occupation. The most important opium-growing provinces were Xieng Khouang Province in northeastern Laos and the Thai country of northeastern Tonkin. Both regions had a high concentration of Meo (Hmong) tribesmen. The French rigorously intervened in the tribal relations and conflicts by choosing Touby Lyfoung as their opium broker in Laos and Deo Van Long in the

27 K. Quincy, p. 1.

28 It is a similar fate to the Ambonese and Moluccan collaborators of the Dutch colonial regime: after the lost Dutch war of 1945-1949, they could stay in the Netherlands as a discriminated minority, which they expressed time and again in a violent way and in the establishment of a "return-to-Indonesia" movement.

29 P. Hillmer, p. 28. 
Thai country. These choices had remarkable consequences for the French colonial future.

\section{Consumption Pattern}

In the following table a comparison is made between most regions of Southeast Asia. The data must have been received from the Dutch Opiumregie. It is not easy to make such a comparison, let alone to check its figures for the simple reason that, in fact, there are no proper sources (the International Opium Commission?). Indochina, here the French colonies only, has the highest sale in kilograms, followed by Siam and the Dutch East Indies. All three had an effective Opiumregie. However, the Indochinese figures can be checked thanks to the excellent study of Descours-Gatin. ${ }^{30}$

She used different kinds of figures so that it is also possible to discover some pattern in the opium consumption of Indochina.

For all regions, one of the most important practical changes was the gradual replacement of the Indian import by the Yunnan import after 1880. For example: of a total import in 1904 of $113536 \mathrm{~kg}$, about 40\% came from Benares and 6o\% from Yunnan. Three years later Yunnan imported already $70 \%$ ( $76317 \mathrm{~kg}$ of $108005 \mathrm{~kg}$.). ${ }^{31}$

But consumers retained their preference for a special taste. Rich Chinese in Cochinchina preferred the Benares opium with a special soft flavor and a low morphine content $(4-5 \%)$. In Tonkin, they liked the rougher, stronger taste of the Yunnan opium with its morphine content of 7- $8 \%$.

Cochinchina (the southern part of the present Vietnam with Saigon) has the highest consumption per head. In 1907 about 50,000 kg was consumed by 90,000 smokers. The Chinese here smoke about $1.5 \mathrm{~kg}$ per annum, while the Vietnamese use only $300 \mathrm{~g}$ on average.

Tonkin is the second largest opium region. In 1907 about 36,00o kg were sold by the Opiumregie (nearly all from Benares). This amount is, however, far from realistic: ' ... according to Inspector Meray the quantities available through fraud equal half the total consumption' (1908). ${ }^{32}$ Meray thinks that about $40 \%$ of adult male Chinese are smokers, whereas this

\footnotetext{
30 In particular C. Descours-Gatin, p. 209-222.

31 C. Descour-Gatin, p. 209-210.

32 Idem, p. 210.
} 


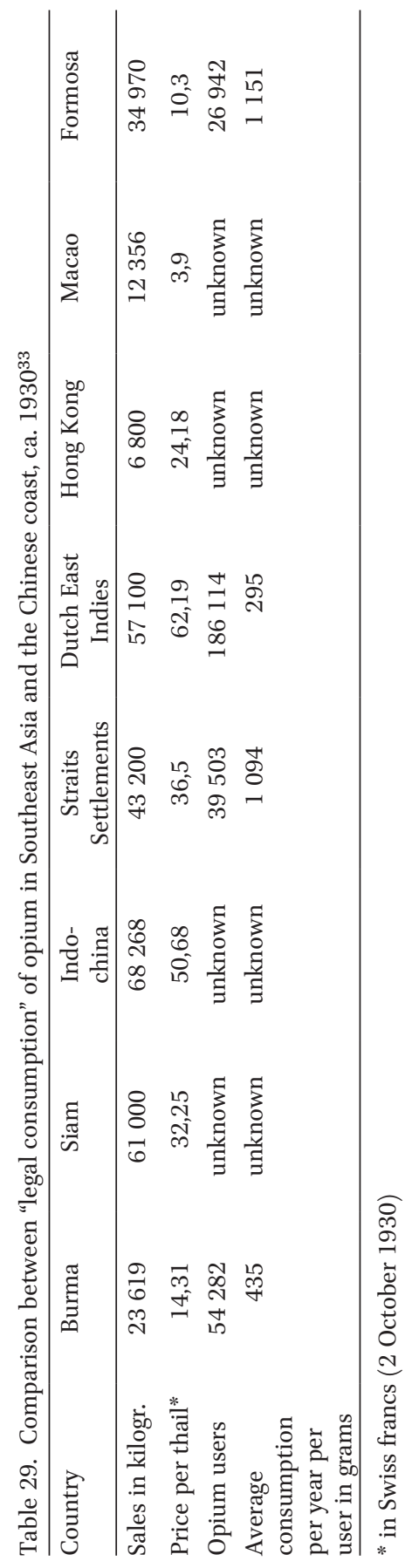




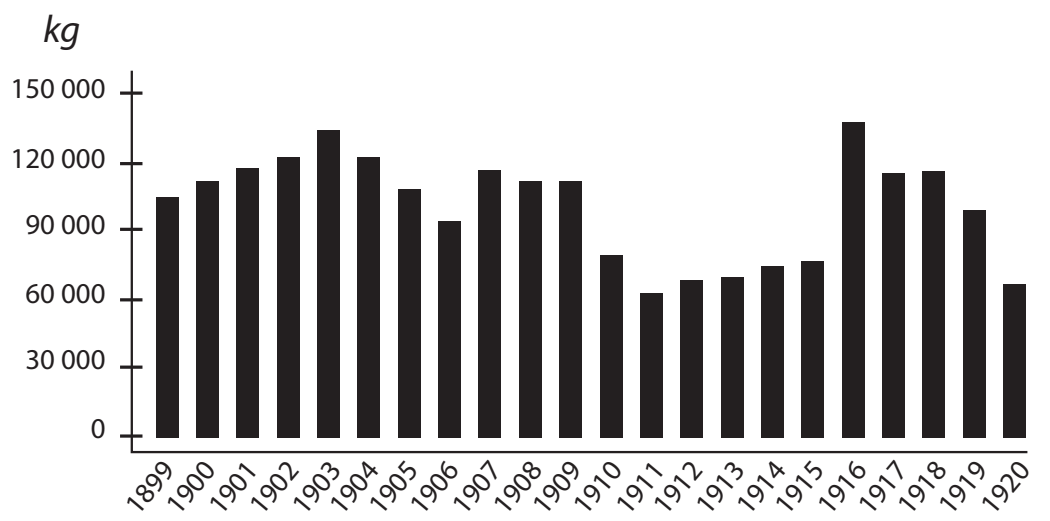

Figure 10. Opium Consumption in Indochina, 1899-1920

Source: C. Descours-Gatin, p. 218. For the years 1899 to 1907 the data are according to the Inspection Meray, appendix to report 61; for the years 1908 to 1920 is used Inspection Merat, appendix II.

percentage is only $2.5 \%$ among the Vietnamese. Others are of the opinion that indigenous people do not smoke at all: only the Chinese are opium consumers. The representatives of the tribes all react differently: among the Chams, Khas and Mois minorities, the “opiomanie" is 'quasi unknown'. Among the mountain tribes, Meos and Mans, in Tonkin, who have a poppy culture, there should be a very limited number of smokers.

Amman and Cambodia consumed more or less the same quantity of opium in 1907 according to the Opiumregie administration, 10,124 kg and 13,560 kg, respectively. They have, however, different characteristics: the first has nearly double the number of smokers, and in Cambodia $60 \%$ of them are Chinese, smoking about $1.4 \mathrm{~kg}$ per year, whereas in Annam the Chinese smoke on average $1.7 \mathrm{~kg}$. In Annam, furthermore, they smokes almost only Yunnan opium, while in Cambodia they have just the Benares form; in the latter there are 572 opium dens, but in the former not one. And so on.

Laos is a different case, although this could be the result of contradictory figures. First, the opium comes exclusively from Yunnan. In 1907 the Opiumregie sold 4,716 kilo of opium there. They say that this assumes a consumption of 10 gram peryear, a quantity by which nobody can become an addict, not even a regular smoker. This would give, however, an unreliable smokers population of 471,6oo people. And with a factual population of about 630,000 this, in turn, would lead to $6,300 \mathrm{~kg}$ consumption or a 
smokers population of $75 \%$. In addition, according to specific reports there are serious regional discrepancies, with some having only $2-3 \%$ of the adult men smoking, whereas along the Mekong river this rose to $30-35 \% .^{34}$ The "smuggling" is here also widespread and very easy to do. For Laos there were no data given, so I estimated some in line with other parts of the French colonies.

The above is more or less summarized in the following table.

Table 30. Opium smokers in Indochina in $1906^{35}$

\begin{tabular}{lrrrlrc}
\hline $\begin{array}{l}\text { Land or } \\
\text { region }\end{array}$ & $\begin{array}{l}\text { Total } \\
\text { Population }\end{array}$ & $\begin{array}{l}\text { Chinese } \\
\text { Cmokers }\end{array}$ & $\begin{array}{l}\text { Total } \\
\text { sminese } \\
\text { smokers }\end{array}$ & $\begin{array}{l}\text { Total } \\
\text { Chon-Chinese } \\
\text { smokers }\end{array}$ & $\begin{array}{l}\text { Chinese } \\
\text { smokers }\end{array}$ \\
\hline Cochinchina & 3000000 & 4,7 & 90000 & 20000 & 70000 & 22 \\
Annam & 5000000 & 0,12 & 23000 & 2500 & 20500 & 11 \\
Tonkin & 6000000 & 0,7 & 132000 & 9000 & 123000 & 7 \\
Cambodia & 1600000 & 7,16 & 12000 & 7200 & 4800 & 60 \\
Laos & 630000 & 0,08 & $18000 *$ & $1000^{*}$ & $17000^{*}$ & $6^{*}$ \\
Total & 16230000 & 1,9 & 275000 & 39700 & 235300 & 14 \\
\hline
\end{tabular}

* Laotian smokers are "real" estimates and, therefore, the totals as well

A comparison with the Burmese consumption is revealing. The figures used by the CIA in the 1950 os must be derived from the estimated annual production of 150 tons, of which 120 tons were exported:

It is estimated that 60,000 opium addicts, concentrated principally in the producing areas and in the Bhamo and Myitkyna districts, consume 30 tons of opium a year ... This estimate is derived by assuming that the annual consumption of a Burmese addict is similar to that of a Thai addict: 500 grams a year. ${ }^{36}$

The consumption figures of so-called addicts given here are fully in variance with those revealed above with differences ranging between 10 grams, 500 grams and 1.5 kilo a year. These differences result not only from ignorance and inaccurate reporting, but to a large extent from wrong definitions: a smoker is not necessarily an addict, while an addict is always a smoker in these regions; it is, furthermore, utter nonsense to call a 500 gram smoker a year an addict; in an earlier table, in which a comparison is made between several Southeast Asian countries in 1930, some 54,000 'opium users' are mentioned, the most vague definition possible.

\footnotetext{
34 Idem, p. 213 and note 45.

35 Idem, p. 214 rounded figures.

36 Central Intelligence Agency, p. 8.
} 
After World War II and the Japanese occupation the situation in Southeast Asia became quite chaotic with a war of liberation against the French or several military coups and assassinations with an ethnic background. The reports of the CIA are one of the few sources available and they are used with caution.

Table 31. Estimated Number of Opium Addicts and Consumption of Illicit Raw Opium in Indochina and Singapore-Malaya, $1955^{37}$

\begin{tabular}{lcc}
\hline Province & Number of Addicts & $\begin{array}{l}\text { Illicit consumption in metric } \\
\text { tons }\end{array}$ \\
\hline South Vietnam & $55000^{\mathrm{a}}$ & 30 \\
North Vietnam & 60000 & 45 \\
Laos & 10000 & 8 \\
Cambodia & 20000 & 15 \\
Total Indochina & 145000 & 98 \\
Singapore + Malaya & 115000 & 100 \\
\hline
\end{tabular}

a 'Approximately 15,000 of these addicts receive legal opium "detoxification" doses from governments stocks rather than illicit opium.'

This table covers the same realm as in the previous one. The largest differences concern "North Vietnam" which is the earlier Annam + Tonkin. This cannot be explained only by the use of different definitions (addicts versus smokers). For South Vietnam (former Cochinchina), a source is accidentally mentioned: 'Mr. Tran Van, a Deputy Director of the South Vietnamese Police and Sûreté'. This man estimated the annual consumption in his province at about 36 to 48 tons, of which about 30 tons arrived through the illicit circuit.

As a rule of thumb it is estimated that about half the opium produced is consumed locally in these provinces (except South Vietnam). In Laos (now estimated at a population of 1.3 million) there is a slightly different regime. Consumption does mean here probably 'the amount retained by the Lao after the official collection'. The largest part of the opium retained after the official collection 'was purchased by private opium dealers and resold in Indochina, Thailand, Burma and Communist China'. The smallest part is estimated 'at about 68 tons'. ${ }^{38}$

In particular, the strategically important Laotian production-consumption is treated in a bewildering way as follows. It is already difficult

\footnotetext{
37 Idem, p. 13. The data for Singapore are added from Idem p. 15. The report used 'disintoxication' in stead of 'detoxification'.

38 Idem, p. 14.
} 
to make a connection to the 8 tons in the table and the 68 tons of what is called 'personal consumption by the Lao'. However, the following rather spectacular description can be partly an explanation for the bewildering figures:

Thus, total consumption in Indochina could amount to approximately 100 tons a year. As approximately 125 tons of opium are produced annually in Laos, approximately 25 tons of Laotian opium are available for hoarding and for export to other countries. Opium is sold quite openly in Laos. $[\mathrm{X}]$ recently reported: "Opium can be purchased in village markets in Sam Neua ... Luang Prabang and Xieng Khouang provinces, as well as in the northwest. It can be bought right in the town of Xieng Khouang." With a readily available source of supply at competitive prices, opium smuggling from Laos is a relatively large-scale operation. Airplanes and trucks, both civilian and military, are used extensively for the clandestine movement of opium from the Laos collection centers to the markets. ${ }^{39}$

I can only point to this situation as a demonstration of what can be done with statistics, while I am not in a position to do new research on this matter. And that is necessary, not only for the Burmese case, but for the whole of the Opium Problem. Since the Myanmar narco-military regime belongs today to the largest opium and or heroin producers in the world, it is worthwhile to re-examine this country for the period up to the 1950 .

\section{Myanmar (Burma)}

Quite at the beginning of his interesting study, Ronald Renard provides us with a most relevant opening sentence:

Involved parties ... agree that it was the British who were mainly responsible for introducing opium to Burma proper on a large-scale basis. Although ... the British were not directly involved in developing the cultivation of opium as a major cash crop in the Shan areas of Upper Burma, the role of the East India Company in spreading opium to Burman areas and popularizing it there is undisputed. ${ }^{40}$

39 Idem, p. 14. If 68 tons is the consumption in Laos only and its production 125 , than 57 tons remain for export. Apart from this, 100 tons are mentioned as consumption for the whole of Indochina including the Laotian 68: this leaves $3^{2}$ tons for all the other Indochinese countries or provinces. According to the table 145,000 minus 10,000 (=Laos) addicts must be served with 90 tons. From where do the missing 58 tons come? This apart from 25 tons mentioned for hoarding, etc.

40 R. Renard (1996), p. 2, 3. 
Once told this, it is senseless and a-historical to start a new chapter about early drug use with an unproved and unprovable story about $1000 \mathrm{BC}$ or $800 \mathrm{AD}$ in which it seems as if cannabis or opiates are used: by whom? how much? how? imported? grown oneself? If one cannot answer questions like these with some kind of certainty, then it is much better not to speculate. That is, besides, an art in itself. ${ }^{41}$

The year 1519 in which the ruler of Martaban made an agreement with the Portuguese to bring opium has parallels elsewhere (China). But it still does not provide any relevant information.

The further historical information is mostly useless. A son of a king at the end of the 16 th-century died from opium, whereupon the sentence follows:

However, there is virtually no mention of opium or alcohol in the Burmese chronicles until the nineteenth-century. By this time, usage was more widespread, although the elite still shunned it. A 19th-century observer noted that "a respectable Burman would hesitate to be seen around a Government-licensed [liquor] shop" and that opium use among the "better classes of Burmese is extremely rare. ... Burmans have no taste for ganja". ${ }^{42}$

The British penetrated China not only from the sea, they tried later to enter it through Tibet. During the British conquest of Burma from 1885 onwards, exploratory expeditions were sent particularly to the border regions with China (Third Anglo-Burmese War). Here one expected trade routes into China, the "Golden Road to Cathay", among others for their opium. It is perfectly possible that the tribal poppy cultures on the other side of the practically non-existent border, in Yunnan or Szechwan, were an off-shoot of this Burmese conquest. The fact is that poppy cultures among the hill tribes started to flourish only after the Opium Wars with China (see ch. 30).

The story goes that an early James Bond, the bagpiper Sir James Scott, discovered many hectares with poppies in the 1890 in the Shan state that resembled rice fields. Other discoverers soon arrived here in Kokang and gave their own, very differing estimates of the availability of opium. They vary from 4,000 to 30,000 hectares $!^{43}$

41 If I see on the kind of sources on which this "ancient old" information is based (a Police Journal from the year 1941; an obscure magazine like the Burmese Mooyit), I have to question the procedure followed even more.

42 Idem, p. 16.

43 Idem, p. 28. 
As a good bookkeeper Scott estimated a yield of $2.6 \mathrm{~kg}$ per hectare with a market price of 6-7 rupees (= about $£ 1$ at the time) per kilo just after the harvest and 10 rupees during the off-season. Whatever the estimates, this price leads to a substantial income for the region. Its popularity was greatly increased during a convention of the League of Nations (1930), when it was declared that Kokang opium was 'the best in the world', thanks to its high morphine content!

By 1900 opium was, anyway, the dominant crop in the Kokang region. From here the cultivation spread to other areas, while cultivators came from several directions. We could expect to find reports of how the practice of opium smoking, trade and smuggling increased rapidly. Scott's assessment of the use in 1900 is expressed as follows:

It is to be noted that there are no victims of opium in these opium-producing districts, any more than there are in Ssu-ch'uan, where the people are the wealthiest in China and half the crops are poppy. It is only in places where opium is prohibitive in price that there are victims to opium. There to buy his opium, the poor man must starve himself. He dies of want and opium is blamed. Where opium is cheap, the people are healthy and stalwart. East of the Salween, the universal opinion of opium is that of the Turk, who stamps on his opium lozenges Mash Allah, the gift of God. ${ }^{44}$

To underline his view, Scott refers to opinions among hill-tribes like the Lahu or Akha who 'smoke opium because [they claim] it is the best thing for their health they know of. In other tribes, like the Shan, Kachin or Palaung, however, who had already copied the European cant about opium, they started to lie, acted defiantly or responded hypocritically when questioned about opium use. In his time, according to Scott, in Kokang everybody was smoking opium 'and at all hours'. The rulers of Kokang governed an area so remote and earned profits so large that they did not control anything until the 196os. That was not the case for the rulers of the southern part of Burma, where one had far greater opium problems.

And the British occupiers?

It was to opium revenue that many British colonial officials became addicted. Not only did this differentiate them from the Burman rulers in the past, who had little if any use for opium or its revenue, this addiction also kept the British from ever taking serious actions to finally eliminate opium. ${ }^{45}$

44 Quoted in Idem, p. 29. Apparently "Ssu-ch'uan" is the same as the Chinese province, Szechwan. The Salween is a river originating in Tibet and ending after nearly 3,00o kilometer in the sea near Rangoon in the south of Burma.

45 Idem, p. 30. 
The latter is a euphemism, since following the British takeover the opium consumption immediately grew rapidly thanks to the promotion campaigns of the EIC and the British colonial government in India. It was the Burmese authorities and the Mon Buddhists who strongly opposed the spread of opium use. Anti-opium tracts soon appeared, and demonstrations were held of hundreds of elders who went down on their bended knees with their head on the ground to implore that 'the opium plague should be removed ...' These elders were even willing to pay to compensate a loss of the Government's opium revenue.

And indeed, King Bodawpaya prohibited opium consumption in 1826, making it a capital offense in the Burmese state. After fierce British pressure a commercial treaty between the king and the viceroy of India was concluded in which, of course, trade in opium was permitted (1862). But sixteen years later there came a real Opium Act for Lower Burma (in 1888 also for Upper Burma) with royal sanctions against opium use. A remarkable aspect was that this act was not restricted as elsewhere to Chinese only or to any registered opium user in Lower Burma. Opium shops were closed down throughout Burma except in Rangoon, and so a whole network of anti-opium rules and laws gradually came into being. ${ }^{46}$ Widespread actions against cannabis were launched as well.

Not many figures can be found about later years, but Balfour writes that in Burma the import 'has greatly increased, even more rapidly than the population'. ${ }^{47}$ The consumption of 1869 had doubled ten years later; one reason for this was the continuous flow of Chinese immigrants

and their use of the opium pipe is without any bad results. Amongst the Burmese, however, the demoralization, misery, and ruin produced by opium-smoking presents a painful picture.

But Chinese traders also played a role, as a Norwegian explorer remarked in 1881:

Occasionally a caravan of Haw or Yunnan traders brings a fresh supply of merchandise into the city, principally wax ... [and] opium, a great quantity of which they smuggle under their wide coats and trousers .. ${ }^{48}$

The Burmese elite, under the influence of all kinds of modernisms brought by the English, started to develop a nationalist creed from the 1920 s onwards. A historical theory was adapted in which the Burmese tribe was

\footnotetext{
46 In a useful appendix (Idem, p. 115-123) Renard has listed all measures from 1782-1991.

47 E. Balfour, vol. 3, p. 37 .

48 A. Maxwell Hill, p. 8, 9.
} 
perceived as a nation, whose kings had by feats of valor created a Burmese kingdom (Golden Peacock throne) subordinating most tribal lands, dynasties or people like the Shan, Arakan, Karen, Chin and so forth. 'This unity was shattered by Britain, the kingdom dismembered, and separatism encouraged in keeping with the divide and rule strategem of foreign imperialists. ${ }^{4} 9$

The British left in 1948. It is the year in which one of the few indigenous politicians who could keep Burma united, Aung San, was assassinated with his whole cabinet by Burmese coup-plotters. This was the beginning of a new wave of bloodshed and wars among "Rangoon" and nearly all tribal states. Furthermore, hundreds of thousands of persons, mainly of Indian descent, emigrated. The Burmese middle class "disappeared", leaving the economy in shock, from which it still has not recovered. The consequence was that the remaining people had to rely on an active black market fostered through a strong exchange of goods between Burma and Thailand.

This situation was highly favorable to the opium business and the rise of Burma as one of the main narco-countries. The CIA assessed this as follows:

Opium is exported from Burma to overseas markets by sea from Rangoon and, after traveling through Thailand, from Bangkok. It is estimated that 30 tons were exported from Rangoon in 1955. This estimate is based on the following considerations: (a) it is estimated that 12 tons were exported to Singapore and Malaysia in 1955 from Burma [see table 35, p. 467 H.D.], and (b) Rangoon is one of the two principal supply ports for the Hong Kong and Macao markets. The opium traffic from Burma to Thailand is much larger than the shipments from Rangoon and is estimated to amount to approximately 90 tons. ${ }^{50}$

It is interesting how this report continues with a table in which the accelerated increase of opium prices is given relative to the distance the opium had to travel. The transport concerns 90 metric tons and about 1,500 km:

49 C. T. Yawnghwe, p. 51. The author, himself a Shan nationalist, immediately added that this perception 'does not quite fit the facts', pointing to the language policy of the British to make English the national language. This must be a proof that one state was desired over separatism. He forgot that every European colonizer wanted its language to become the dominant one, but that politically the indigenous opposition was fought in endless battles and that it was a standard policy to prevent by all means a united front arising against the foreign rulers. Divide and rule by force or by bribes, and therefore, being friendly to one group (like the Shan nationalists!) and angry against another, and so on.

50 Central Intelligence Agency, p. 8. 
Table 32. Value of Estimated Exports of Opium from Burma to Thailand at Various Stages of Transport, $1955^{51}$

\begin{tabular}{lc}
\hline Stage of Transport & Value in wholesale prices x \$1000.- \\
\hline Producers location & 1350 \\
Kentung, Burma & 3970 \\
Thai-Burmese border & 5310 \\
Chieng Mai, Thailand & 6840 \\
Bangkok, Thailand & 9540 \\
\hline
\end{tabular}

In 1988 the World Bank estimated that $40 \%$ of Burma's gross national product (US\$3,00o million) changed hands on the black market annually.

This has been immensely profitable for the Karens and other rebels since the start of their rebellion in 1948. The Burmese government controlled only a few isolated points on its eastern border, so that the rebels could easily conduct big business to finance their military activities. ${ }^{52}$

\section{Thailand (Siam)}

Shallow historical evidence reveals that opium (or something which was designated as such) played some role in early Thai history. There is a law from $135^{\circ}$ pertaining to banditry stipulating that the public was prohibited from smoking, eating or selling opium. This cannot be considered reliable information. ${ }^{53}$ The next mention of opium apparently concerns a late 18th-century source from the Bangkok Period. In the 19th-century Kings Rama I to IV decreed that those caught with opium must be punished, apparently an offense of the elite: confiscation of property; the defendant's families and slaves would become property of the realm; the opium was to be destroyed or publicly burned by monks. These performances received a specific name, kratham chapanakit phao fin, opium cremations. One of these kings undermined his own anti-opium regime in the 1840s:

51 Idem, p. 9.

52 R. Renard (1996), p. 47.

53 T. Chaloemtiarana, p. 125. If this concerned opium, business on a rather large scale must have been carried out for some time. I know at the time no poppy growing, processing or exporting took place in the Far or Middle East with trade relations to this region. See also D. Duco, p. $55 \mathrm{ff}$. 
Rama III's attempts to control trafficking in the drug were unsuccessful, however, because of the great profits to be had from the illegal opium trade. Accordingly, the government of Rama III began importing opium from India and selling it by auction to the highest bidders, who were called nai akon, or tax officials. ${ }^{54}$

Whether this happened on his own initiative or a foreign one is not known. Anyway, the next king, Mongkut (1804-1868), returned only partly to the old prohibition policy by restricting the opium use to the Chinese community. Thais were prohibited again and from that time on opium became associated with the rise of Chinese secret societies. It was an attempt to corner the opium market, as if Chinese needed secret societies to get free opium. This approach, in the framework of the so-called 'bamboo policy', was certainly fixed under the pressure of the EnglishChinese Opium War and the American threatening of Japan (1854). 55

Chinese secret societies did not have much to do with this, but they feared being the next target of the Western assaults. Therefore, Mongkut quickly made a deal with the English through the governor of Hong Kong, Sir John Bowring, as official representative of Queen Victoria. Sir John arrived with his personal steamship in Bangkok (1855). The result of this very British demonstration was a costly treaty for both parties: Mongkut had to abandon the traditional system of princely monopolies and farmings, the main income of his household, in favor of a simple importexport system which allowed the British to import, for instance, opium when and how much they liked. The prince was left with $3 \%$ import duty.

That the British were also allowed to rent or buy land and houses near Bangkok gave them the opportunity to establish an English settlement to control the implementation of the new treaty and to organize the selling of British opium in Siam.

That was not all: within a few years time Mongkut was forced to conclude similar treaties with France and the United States (1856), Denmark and Portugal (1858), the Netherlands (1860) and several other Western countries which smelled profits. Although they had never read the Illias, Mongkut and his successor Rama IV experienced the effects not of one but of many Trojan horses: in 1867 Siam lost its power over Cambodia to the French, and so on. Envy arose among Westerners regarding the fine position Bowring had obtained for the English. ${ }^{56}$

\footnotetext{
54 T. Chaloemtiarana, p. 125.

55 See the article of Henk Zoomers in R. Feddema (ed.), p. $42 \mathrm{ff}$.

56 Explicitly mentioned by a Dutch negotiator with the Siamese authorities. See Idem, p. 57. This negotiator, Loudon, is highly arrogant and discriminating vis-à-vis the Siamese
} 


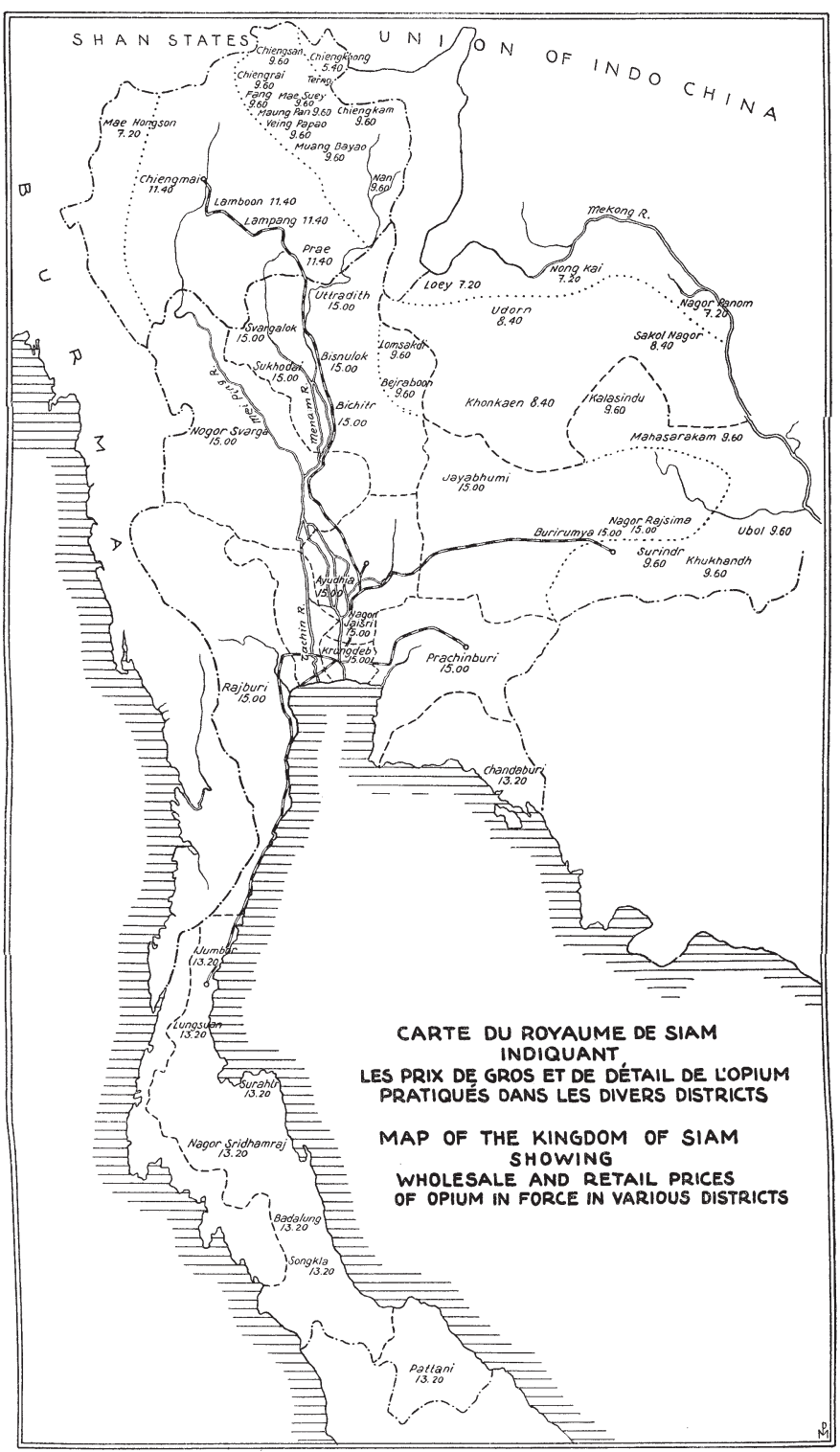

Map 14. Prices of Monopoly Opium in force in various Siamese Districts, ca. 1930 Source: Commission d'Enquête sur le Contrôle de l'Opium. League of Nations.

rulers: it is a shame that Bowring had given these childish simple 'Toeans' a prince-like status, who did nothing but established a harem and smoked too much opium (L. writes remarkably enough about 'belladonna'; idem, p. 59). 
Although all powerful families in Siam lost thanks to the "Bowring treaty", the influential Bunnag family could compensate for this by strengthening its already strong position in the opium, alcohol and gambling business by increasing the prices. ${ }^{57}$ The specific relation it had developed with its main consumer group, the Chinese, must have made the Bunnag family enemies. It is probably in this inimical atmosphere that the idea and probably the practice of Chinese secret societies arose.

Still, secret societies exist and certainly in the fully corrupt scene of Thailand's elite, where until long after the Second World War 'opium remained an official source of government revenue in Thailand, becoming a major source of corruption and power'.

This power became gradually divided between the police and the army, police general Phao Siyanon and army general Sarit, respectively. The former controlled the local opium trade and used it to finance his police machine; the latter became the leader of the country, a despotic paternalist, through a coup in $195^{8}$. Sarit's power base was strong military support of the USA's anti-communist policy.

Sarit hated hoodlums, opium, uncleanliness and social impropriety. Therefore, no long hair, rock-and-roll music, modern dancing, tight pants, and so on, but also no dirty roads, littering, stray dogs or beggars. Urbanized youngsters from the villages driving 'pedicabs' and using opium were the main target of Sarit's arrests. In a few years time nearly 8,00o were caught, sentenced for a month and mostly sent to reform institutions to be "re-educated". 58

One personal hobby was to fight arson and fires, which often occurred in times of depression and sometimes with devastating effects. Sarit used these events to blame unpopular groups, e.g. Chinese or communists. They "confessed"-before they themselves were executed-to setting fires in the framework of a larger plan to create chaos.

After his coup Marshal Sarit announced his 37th proclamation with the words:

Now, the designated time has arrived. The first minute after midnight on July 1, 1959 marks the ultimate termination of opium consumption in Thailand ... The sale and use of opium are illegal ... Alien offenders will be deported, and Thais will be marked as traitors who refuse to make sacrifices for the nation, which is equivalent to not cooperating with me personally

\footnotetext{
57 Idem, p. 52.

58 T. Chaloemtiarana, p.121 ff.
} 
... I can sacrifice even my life. I consider that opium is a national menace, and I will do anything to save the nation. ${ }^{59}$

Opium dens were meant to be closed within six months, treatment centers were established to help addicts, 43,00o opium pipes were publicly and ceremoniously 'cremated', heroin producers in Bangkok arrested. The decision to wage all-out war on opium and heroin brought fame to Sarit and earned him the respect of the public.

This act of moral purity was counteracted, however, by Sarit's substantial cruelty and corruption to enrich himself, his family, eighty mistresses and friends. Upon his death (1968) they all quarrelled over about approximately US $\$ 140$ million. Not opium but women, gambling (lottery) and excessive drinking appeared to be his weak spots. The Thai opium dossier will have to be explored in another publication. ${ }^{60}$

\section{Malaysia (Melaka, Malacca) and Singapore}

From the middle of the 18 th-century, the Malays and other inhabitants of Melaka had many reasons to question the VOC's military preparedness. ${ }^{61}$ For at least a century the Dutch were the dominant power. However, the serious conflicts between the commercial Bugis of Sulawesi and the Malays from around $175^{\circ}$, in which the latter asked for the protection of the Dutch, showed an unexpected weakness of the VOC.

In exchange for their help, the Malays Sultan Sulaiman promised the Dutch toll-free trade and other privileges. The lethal attack on the Bugis was planned by both. They did not wait, however, but took the initiative and laid siege to Melaka, burned houses in the suburbs and even raided the town itself. It was a shocking experience for the Malays, and in the following decades these events only strengthened the position of the Bugis.

The Dutch were not able to retaliate until 1761, but it was the last active Dutch campaign. Once they discovered that the cost of their presence in the region was becoming prohibitive, all parties realized what a contemporary observer expressed. He compared the VOC 'to a man infected with a creeping disease which, if not cured in time, would prove fatal'. A few years later it was over and out for the VOC.

\footnotetext{
59 Quoted in Idem, p. 126.

60 The start of it is described in C. Lamour, M. Lamberti, passim.

61 For the following see B. Watson-Andaya, L. Andaya, p. $97 \mathrm{ff}$.
} 
Its main competitor, the EIC, became gradually more important because the English controlled the cloth-producing and poppy growing areas in India after "Plassey".

Malays had been smoking opium mixed with tobacco since the seventeenth-century, when the Dutch began importing the drug into the area. A hundred years later their consumption had reached such heights that the Governor of Melaka could tell his superiors that "the people of Rembau, Selangor and Perak, like other natives, cannot live without opium", while Chinese accounts show that east coast Malays were equally addicted. No entrepot could compete in this new economic environment unless it had ready supplies of opium, and in 1786 Francis Light was to recommend the import of large quantities of the drug to Penang specifically to attract merchants. ${ }^{62}$

In particular, the English country traders, speaking fluent Malay, were highly successful thanks to their smuggling of weapons and opium, which were forbidden by the VOC. It was around 1800 that the region definitely became an important trading center on the road between India and China.

The main beneficiary on the indigenous side was the Bugis-controlled Riau archipelago, the 'key to the Straits'. Here vessels from all over the region flocked to trade: Riau became the principal point of exchange for smuggled spices, opium and other products like tin or cloth.

Instead of the Dutch, the British took over in the region. Singapore strengthened its position as holder of the "(military) key of Asian trade" and as center of tin mining, rubber plantations or shipbuilding. The whole peninsula and the opposite Sarawak (North Borneo) became a most strategic position. As explained in ch. 2, the relationship Raffles-Farquharopium tycoon Matheson resulted a century earlier in the (re)establishment of Singapore and surroundings as the internationally well-known pleasure center and "one big opium den" with all possible nasty consequences.

Newbold reported about 'that pernicious drug, opium' as the second main article and nearly equal in value with the first, Indian and other piece-goods (the third is tin):

The total value of this article imported in the year $1835^{-6}$ amounted to the enormous sum of upwards of a million of dollars. Two hundred and fifty two thousand of which was the value of the quantity exported to China, most part of the remainder went to the east coast of the peninsula, to Java,

62 Idem, p. 100. 
Borneo, Celebes, Cochinchina, and Siam, and a considerable quantity to America. The opium trade with China is contraband. The total value exported annually from Calcutta and Bombay to the East is supposed to amount to about $3,000,000 \mathrm{lbs}$. The Patna opium is the most prized ... and sells from 710 to $720 \mathrm{Sp}$. drs [per chest]. Benares sells from 645 to $65^{\circ}$ Sp.drs, and Malwa from 580 to 600 Sp. drs. Turkish opium, though disliked at first, has latterly come into greater demand. ${ }^{63}$

Here is demonstrated how Singapore was in the earliest phase already a world distribution center of opium; the "brand new" United States were not free from this 'pernicious drug'. ${ }^{64}$

There was, however, another side to this medal. In the period that the English had to earn their fortunes as owners of mines, plantations or banks, and as narcotic dealers or smugglers, they detested the Malays as too lazy to do the dirty work in the tin mines or on the rubber plantations. The British opium smugglers-investors used their lively trade with China to bring back a substantial Chinese labor force for the tin mines, plantations and, later, as operators of the tax farms.

Around 1835 the best paid Chinese hand-laborer got from 4-6 Spanish dollars a month and a Malay only $\$ 2.5-4.5$. A skilled Chinese man like a carpenter got about 15 dollars, whereas a skilled Malay carpenter received only 5 dollars per month. Adult Malay women employed in weeding and similar work got $3-8$ cents a day. ${ }^{65}$

As a rule of thumb the British believed that this import of Chinese workers was a reliable index of economic progress. They were right. The global framework changed drastically between the beginning of the 19thcentury and the end of the Opium Wars. It is well described by Trocki:

Most important was the expansion of the global market communicated to Singapore through the major trades: opium, capital, and manufactures from India and the West. Pepper, gambier, tin, and the other major commodity flows generated in Southeast Asia originally moved with the Western trade to China. ... In addition to redirecting the commodity flows to the West, the

63 Th. Newbold, vol. 1, p. 363 . Also elsewhere (Id., p. 57) he writes about 'that most debasing and pernicious drug, opium' in combination with the Chinese secret societies 'of which spring many of those daring outrages and robberies that disgrace our settlements.' See the article of B. ter Haar about 'secret societies' in D. Leese (ed.), p. 883-885.

64 See Th. Newbold, Idem, p. 20, which reported that there was a commercial convention between Great Britain and the United States (1815), which restricted the American privilege of trade to Calcutta, Madras, Bombay and Prince of Wales' Island. Singapore was not mentioned because it did not yet exist (1818). An American tried to enter Singapore in 1825 , but was "arrested". But 'an inconvenient and clandestine sort of traffic was still maintained' (Id., p. 21), until the matter was solved.

65 Th. Newbold, vol. 1, p. 14, 15 . 
shift created a vast demographic eruption. It was as if the current of wealth flowing out of China began to pull with it the Chinese peoples themselves. Singapore came into being as a result of these global forces ...66

Opium played in this global shift the most crucial role. Singapore's opium scene in the 19th-century is, therefore, much more important than only in a local or regional context. It can be summarized in a table in which the whole constellation is symbolized. Trocki's central thesis that the British Empire in Asia was built on opium is certainly supported by the fate of Singapore. Together with Hong Kong, Singapore represents the fate of this empire. Officially, nearly half of all revenues of the British was earned here by opium, as the next table shows. This concerns, of course, only the colonial profit for the British. It cannot demonstrate how much private or individual British officials, military men or bankers earned. Indirectly, it also suggests how much a very few super-wealthy people (Chinese) pocketed as their share of the opium rents in this century.

Table 33. Singapore Opium Farm Annual Rent, 1820-1882 (selected years; in Spanish $\$)^{67}$

\begin{tabular}{lrcc}
\hline Year & Rent (x 1000) & $\begin{array}{c}\text { Total Revenue } \\
(\text { x 1000) }\end{array}$ & $\begin{array}{c}\text { Percentage 2 } \\
\text { from 3 }\end{array}$ \\
\hline 1820 & 7 & 16 & 46 \\
1825 & 24 & 76 & 32 \\
1830 & 39 & 96 & 41 \\
1835 & 58 & 119 & 48 \\
1840 & 65 & 143 & 46 \\
1845 & 108 & 232 & 47 \\
1850 & 88 & --- & --- \\
1855 & 148 & 288 & 51 \\
1860 & 267 & 493 & 54 \\
1865 & 270 & 671 & 40 \\
1870 & 361 & 876 & 41 \\
1875 & 398 & 967 & 41 \\
1880 & 600 & 1277 & 47 \\
Total all years & 11551 & 25669 & Average: $45 \%$ \\
$1820-' 82$ & & &
\end{tabular}

66 C. Trocki (1990), p. 220, 221.

67 Idem, p. 96-97. Instead of the used indication 1820-21 I prefer 1820 etc. All figures are rounded. 
Ellen La Motte added to this table the revenues of the years 1898-1906 as found in a report of the Straits Settlements Opium Commission (February 1909).This report gives all possible details about all possible aspects of the Opium Problem in the Straits Settlements. Among its members the opinions were divided about the harmfulness of opium, but

as a means of raising revenue, the traffic was certainly justifiable. It was proven that about fifty per cent of the revenues of the Straits Settlements and the Federated Malay States came from opium trade and, as was naïvely pointed out, to hazard the prosperity of the Colony by lopping off half its revenues was an unthinkable proceeding. ${ }^{68}$

The table proves probably much better than others how dependent Western colonizers were on the opium business they themselves initiated or-in a positive perception-how successful their invention or colonial exploitation was.

Certainly it is important that Singapore is an axis in the colonial military and trade web of the Western powers. Let us also recall what Crawfurd and Raffles said about "their city" (ch. 2) and how the latter's mission was to make Singapore opium-free! Raffles got a beautiful statue in innocent white marble for it in Singapore.

Little is known about the early opium farms in this port. The British records say almost nothing about their identity or their organization. The British occupiers of the place, like Crawfurd, were only interested in maximizing their profits. They were successful: in the first decade the total revenue increased by a factor of six, while the opium rent in it increased by a factor of $5^{-6}$. The second decade presented only a slight increase for both, which was also the case for the period 1840-1850, apparently as a side effect of the Opium War with China.

Spectacular, however, was the growth in the opium business during the following period, the start of the booming years for the British opium dealers, traders, bankers or shippers and, therefore, also for Singapore, although the competition with Hong Kong wais fierce. The end of the Second Opium War was, of course, the definite turning point for the whole opium business. The British had taken control of the commerce of India, China and Southeast Asia in less than fifty years.

68 E. La Motte, p. 24. For 1898 the opium revenue was $46 \%$, in 1901 it had increased to $53 \%$ and in 1904 even to $59.1 \%$. 


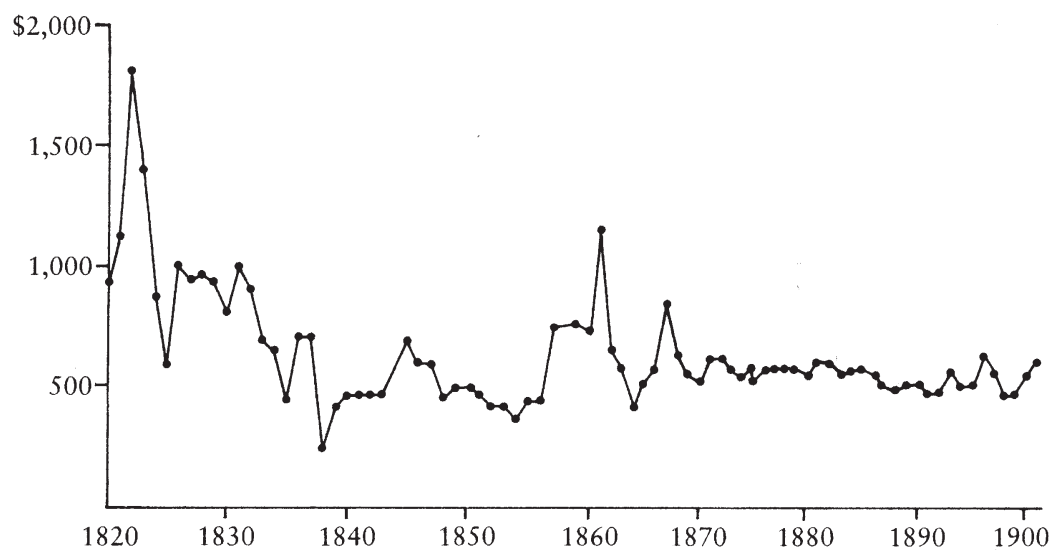

Figure 11. Average annual opium price in Singapore, 1820-1901 (Spanish dollars per chest).

Source: C. Trocki, 1990, p. 59. Compiled from various issues of SFP and ST.

It is difficult to see how the British succeeded in doing this without opium. It was the major form of economic leverage. ${ }^{69}$

The table of Singapore's opium export in Appendix 1 complicates this picture for, at least, the period 1830 to 1870 .

We could have expected that when such enormous amounts of money are earned in a very cheap way by relatively few people, they would make a deal in order to divide the profits fairly. Instead, the reverse occurred: the parties involved became greedier and the mutual struggles increased. One thing remained relatively quiet after the Second Opium War: the opium prices. In the preceding period the competition was fierce, the political and economic situations unstable, the fate of the individual dealers uncertain.

For Singapore, Trocki identified and described in detail the fate of four "parties" involved in the 19th-century opium business: the British merchants and officials; Malay chiefs; Chinese merchants and revenue farmers; Chinese kongsis or brotherhoods..$^{70}$ For the Chinese side of this constellation, see next chapter. They were involved or had an interest in a specific side of the Opium Problem: consumption, trade, speculation, control, taxation, etc. Their local games were played in a new world

\footnotetext{
69 C. Trocki (1990), p. 221.

70 Idem, p. $220 \mathrm{ff}$.
} 
economic constellation, which became much more important thanks to the core opium function of Singapore in it.

Singapore as British "Cape of Good Hope" also meant recuperation for everything (ships, etc.) and everybody (leisure, entertainment and retirement home for white, rich colonialists). Quite different images of the Malays were created along with these different functions. The "leisure" image is reproduced, for instance, by a naive expatriate, Frank Swettenham (1913):

The real Malay is courageous ... but he is extravagant, fond of borrowing money and slow in repaying it ... He quotes proverbs ... never drinks intoxicants, he is rarely an opium smoker ... he is by nature a sportsman ... proud of his country and his people, venerates his ancient customs and traditions and has a proper respect for constituted authority ... lazy to a degree ... and considers time of no importance. ${ }^{71}$

Ideal people for those who belong to the 'constituted authority' as the dominant minority of those "English at ease". One may ask where this Swettenham resided. If he had walked along the sandy beach of Pasir Panjang, in the southwestern part of Singapore, he could have visited the House of Tiny Tin Tubes. This was the state-owned opium factory.

In 1910 in Singapore, the development from opium farming to Opiumregie, like elsewhere, was completed by the opening of a modern opium factory. Once the mechanization of opium production and distribution was a fact, mass addiction could be realized. Of course, the usual nursery tales of diminishing opium consumption are told, but the fact is that their factory could produce a million tahils of opium a year or some 450,000 two-hoon tin tubes of chandu daily. A Mr. Walling wrote enthusiastically:

The machines which do this are beautiful, highly technical and impossible for me as a layman to describe. After sealing, they [the tubes] are weighed by delicate, automatic, weighing machines, and packed in small boxes, two hundred at a time. They rest there like miniature Sainsbury's cooking eggs! ${ }^{72}$

However, Swettenham was not a simple English expatriate and was not really naive, because he was the governor of the Straits Settlements. He must have known perfectly well what was going on in his area of "opium jurisdiction", because he personally ran the periodic opium auctions. Furthermore, he was the one who organized the basic transformation

\footnotetext{
71 Quoted in B. Watson-Andaya, L. Andaya, p. 175, 176.

72 Quoted by C. Trocki (1990), p. 224.
} 
from opium farm system into Opiumregie. The following table provides the details, although it suggests that only the Chinese in Malaysia and Singapore used opium. In an ethnically diverse landscape, many groups were available. ${ }^{73}$ Swettenham's opinion about Malays quoted above should be seen as a typical Pavlovian reaction of all foreign Western colonizers to divide and rule the available ethnic groups immediately upon arrival.

Table 34. Estimated monthly costs and sales of selected Malayan opium farms, $1903^{74}$

\begin{tabular}{lcrrrl}
\hline & Singapore & Pinang & Melaka & Johor & Kedah \\
\hline $\begin{array}{l}\text { Estimated Chinese } \\
\text { population }\end{array}$ & 164000 & 98000 & 19000 & $150000^{*}$ & 39000 \\
$\begin{array}{l}\text { Estimated chandu sales } \\
\text { in tahils }\end{array}$ & 140000 & 74337 & 11000 & 80000 & 28000 \\
Gross chandu sales in \$ & 433740 & 230432 & 33000 & 140000 & 76000 \\
Estimated costs in \$ & 138540 & 66749 & 9150 & 58600 & 30200 \\
Opium farm rent in \$ & 215000 & 172000 & 26000 & 80000 & $43000^{* *}$ \\
Spirit farm rent in \$ & 50000 & 45000 & 5000 & 10000 & \\
Net profit or loss in \$ & 30200 & -53317 & -7150 & -9000 & 2800 \\
\hline
\end{tabular}

* This figure was thought to be 'greatly overestimated'

** This figure is the combined opium and spirit farm rent

The table gives an overly pessimistic picture, because the spirit sales are not included, although its rent is. Even in present terms a pure profit of $\$ 30-35,000$ per month (360,000 to 420,000 per year) is substantial for people in the street business. A century ago this was an enormous profit in Malaysia or Singapore. Apart from this, the money capitals which circulated every month among tax farmers or consumers in the opium business (half of the bureaucratic machine of the British) were unbelievable for a region in which wages were counted in cents per day.

Ellen La Motte visited Singapore in January 1917 and stayed in the firstclass Hotel de l'Europe. The first morning at breakfast, she was already confronted with an opium-addicted waiter, 'a handsome young Malay', who was in such a state that it was impossible for him to handle the nor-

73 In 1970 the Malays numbered 47\%, Chinese 34\%, Indians 9\% and among the rest one could find Arabs, Filipinos, Dayaks or Thais. In the Borneo part, the Chinese were between $20-30 \%$.

74 C. Trocki (1990), p. 201. Johor is the first region on the peninsula past Singapore; Kedah is the most northern region on the border with Thailand about 800 kilometer north of Singapore. 
mal breakfast orders. ${ }^{75}$ In her tours through the streets, she was confronted time and again with opium dens selling always the same

little, triangular packets, each containing enough for about six smokes. Each packet bears a label, red letters on a white ground, "Monopoly Opium" ... House after house of feeble, emaciated, ill wrecks, all smoking Monopoly Opium, all contributing, by their shame and degradation, to the revenues of the mighty British Empire. ${ }^{76}$

That evening after dinner she read an article in a copy of the Straits Times (a Reuter's Telegram, 17th January 1917). It concerned a row involving the Chinese in Liverpool: the previous night 31 Chinese were arrested during police raids on opium dens; great quantities of opium were seized; the police were attacked in one place by the Chinese, who threw boots and other articles from the roof. La Motte reflected:

It must be very perplexing to a Chinese sailor, who arrives from Singapore, to find such a variation in customs. To come from a part of the British Empire where opium smoking is freely encouraged, to Great Britain itself where such practices are not tolerated. He must ask himself, why it is that the white race is so sedulously protected from such vices, while the subject races are so eagerly encouraged. It may occur to him that the white race is valuable and must be preserved, and that subject races are not worth protecting ... as if subject races were fair game-if there is money in it ... Is this ... what we mean when we speak of "our responsibility to backward nations" or of "the sacred trust of civilization" or still again when we refer to "the White Man's burden"?'77

Still, this Malaya including Singapore was also perceived as a model colony for the whole of Southeast Asia in the Interbellum. For the British expatriates this country was most attractive as 'a Tory Eden in which each man is contented with his station', because they were in full control of the local elites through a variety of administrative systems. The three "races" were kept in balance: Malays in the paddy fields, "British Indians" on the immense rubber plantations and the Chinese in the shops and tin mines. Indeed, Malaya was the largest producer of tin and rubber, but thanks to the government monopoly in the manufacture and sale of opium half of the country's income still came from this source. The colonial Governor was already familiar with the rationalizations in 1924:

75 E. La Motte, p. 18-22.

76 Idem, p. 20, 21.

77 Idem, p. 22. In 1917 in the official Blue Book was published that the total revenue of the 'Colony of the Straits Settlements' is $\$ 19,672,104$-- and that $\$ 9,182,000 .-$ came from opium (47\%). (Idem, p. 25). 
Opium smoking in Malaya is not the awful scourge believed in by western sentimentalists ... [it] is not doing as much harm as drink in England. It can never be stopped in Malaya ... Smuggling is impossible to prevent, and the money now coming into revenue would go to the smugglers. Any attempt to earmark our opium revenue ... to humanitarian works ... would play the devil with our finances. ${ }^{78}$

This tells us as much about the position of the immigrant Chinese as about opium and their British "masters". The latter acted also in a spectacular way during the Japanese occupation by suddenly issuing a total prohibition of all opium activities immediately after the war (for the period of the Japanese occupation, see ch. 27). However, after the war nothing happened in this direction.

After the war, London still believed: if India was the jewel in the imperial crown, Malaya was the industrial diamond. ${ }^{79}$ Sixteen years later the new Governor estimated (same as his predecessor) that Malaya (Singapore) was 'worth' about £227.5 million to the British Empire; about $50 \%$ must derive from opium. Most of this disappeared mainly to the City of London. Its status as most profitable British colony was achieved, of course, not only by its resources (tin, etc.):

The key to the great public works and civic conceits of the Strait Settlements was opium. Duty on opium accounted for between 40 and 60 per cent of its annual revenue. Its production was monopolized by the government "Chandu factory" on Pepys Road in Singapore which turned out 100 million tubes a year. Much of the revenue burden of Malaya therefore fell upon the Asian, particularly Chinese, labourers who were the greatest consumers of opium. The British crescent in Asia was supported by narco-colonialism on a colossal scale. ${ }^{80}$

This remained at least until the 1960s. A change of opium provider took place: instead of the British Empire opium from India, it came from the Middle East. At the end of the history in this book, Singapore was still considered the primary opium port in the Far East by the CIA. An impression of its importance can be given through the perception of this secret service.

\footnotetext{
78 Quoted by P. Brendon, p. 338.

79 See for the following Ch. Bayly, T. Harper, p. 33.

80 Idem, p. 33 .
} 
Table 35. Raw Opium Seized in Singapore by Country of Origin and Value Imports, $1954-55^{81}$

\begin{tabular}{|c|c|c|c|c|c|}
\hline \multirow[t]{2}{*}{$\begin{array}{l}\text { Country of } \\
\text { Origin }\end{array}$} & \multicolumn{2}{|c|}{$\begin{array}{l}\text { Quantity Seized } \\
\text { (in pounds) }\end{array}$} & \multicolumn{2}{|c|}{$\begin{array}{l}\text { Percent of Total } \\
\text { Seizures }\end{array}$} & \multirow{2}{*}{$\begin{array}{l}\text { Estimated Value of } \\
\text { Imports of Raw } \\
\frac{\text { Opium in US\$ b/ }}{1955}\end{array}$} \\
\hline & 1954 & 1955 & 1954 & 1955 & \\
\hline Iran & 1834 & 2333 & 46,5 & 50 & 19849750 \\
\hline "Yunnan"a & 914 & 965 & 23 & 20 & 5440060 \\
\hline India & 546 & 552 & 14 & 12 & 5513892 \\
\hline Burma & 656 & 547 & 16,5 & 12 & 3705132 \\
\hline Unknown & 9 & 498 & --- & 6 & 2140800 \\
\hline Total & 3959 & 4695 & 100 & 100 & 36649634 \\
\hline
\end{tabular}

a 'This term is used by local traffickers to indicate opium received through Thailand and probably consists of illicit supplies originating in the adjoining areas of the Wa States and Kentung State in Burma, Laos, and North Thailand as well as in Yunnan.'

b CIF values (Cost, Insurance, Freight)

The first five columns of this table do not tell us much about the normal imported quantities of opium, but first and foremost about the ability of the Singapore customs organization. And this 'ability' could also refer to: either the stupidity of the Iranian smugglers or the change they left for the custom officials, but also to the corruption of the Singapore custom officials not to seize the competing opium from "neighboring" Thailand, Laos and Burma.

The Singapore Central Narcotics Intelligence Bureau estimates that the markets in Singapore and Malaya distribute 100 tons of illicit opium annually. The total number of opium addicts in Singapore and Malaya is estimated to be 115,00o. Since neither country has any domestic production, the opium must be imported from elsewhere.

It remains remarkable that, notwithstanding the relative proximity of opium, the Iranian form was preferred. We can assume that this preference was based on ease of import and availability. Furthermore, the high morphine content (9-11 per cent, compared with 6-9 for the "Yunnan" type) seems to have been attractive. ${ }^{82}$

It is more interesting to note how soon close opium relations between the two most important opium-producing regions were realized after the Second World War. CIA reports state that

81 Central Intelligence Agency, p. 16. and 19. In tables on page 17 and 19 the same figures are used as in the \%-columns of table p. 16, but now they have to refer to 'Amount (Metric Tons)'!

82 Idem, p. $16 \mathrm{ff}$. 
a small syndicate of Bahreini Arabs trades in opium on a very large scale from Dubai to Aden, East Africa and Singapore. The opium is procured from Iran and shipped to Aden concealed in cargo where it is transferred to oceangoing vessels ... The town of Qasbat, Iran, is the center for smuggling opium into Kuwait ... Opium smugglers have also used commercial aircraft to move opium from Iran to the Malayan area ${ }^{83}$ Regarding the second destination in the table, it was reported that nearly every ship or commercial airplane arriving from Bangkok carried illicit narcotics, usually opium. Smuggling by airplane concerned a small-scale and intermittently used means. Furthermore, there must have been considerable transports over land and by rail from northern Thailand to Haadyai, apparently the smuggling center of South south Thailand, but also directly across the Malaysian border.

The estimated values of the transports into Malaysia and Singapore reveal that opium was the sixth largest import into both countries. The cost of importing into Malaysia was very high. Apparently, an artificial measure:

Bribes alone are reported to account for almost half of the delivered costs. In 1955, opium could be purchased in Bangkok at $\$ 105,831$ a ton, or approximately 39 percent of the price in Malaysia. ${ }^{84}$

It is a conclusion symptomatic for the general (opium) corruption in the whole of the Southeast Asian realm.

83 Idem, p. 17, 18.

84 Idem, p. 19. 